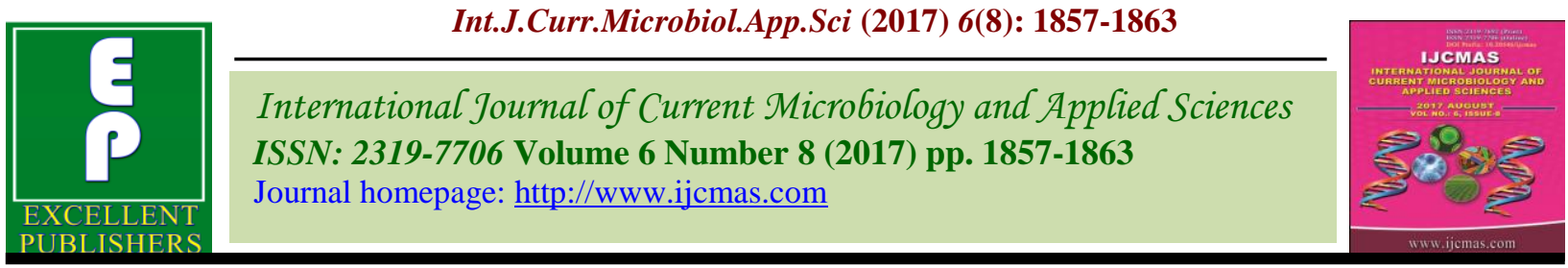

Original Research Article

https://doi.org/10.20546/ijcmas.2017.608.219

\title{
Studies on Genetic Variability, Heritability and Genetic Advance in Pointed Gourd (Trichosanthes dioica Roxb.)
}

\author{
Anil Kumar Jena*, T. Suseela, T.S.K.K. Kiran Patro and R.V. Sujatha \\ College of Horticulture, Dr. Y.S.R.H.U, Venkataramannagudem, \\ West Godavari (Dist.) - 534 101, Andhra Pradesh, India \\ *Corresponding author
}

Ke y w o r d s
Pointed gourd
(Trichosanthes
dioica), Genetic
variability,
Heritability,
Genetic advance.
Article Info
Accepted:
19 June 2017
Available Online:
10 August 2017

Twenty two pointed gourd genotypes were evaluated during Kharif of 2016-17 at College of Horticulture, Dr. Y. S. R. Horticultural University, Venkataramannagudem, West Godavari district, Andhra Pradesh. The objective was to estimate the nature and magnitude of genetic variability, heritability and genetic gain for seventeen important characters. Analysis of variance revealed presence of considerable variability among the genotypes for all seventeen characters. The magnitude of PCV was higher than the corresponding GCV for all the characters studied. Among the characters studied, high PCV and GCV were observed for characters like observed fruit weight $(\mathrm{g})$, pulp weight per fruit $(\mathrm{g})$, pulp seed ratio, number of seeds per fruit, seed weight per fruit, internodal length and fruit yield (t/ha) indicating high variability available in the germplasm for these characters for further improvement. High heritability coupled with high genetic advance as per cent of mean was observed for characters number of nodes per vine, internodal length, node at which first female flower appeared, fruit length, fruit weight, pulp weight per fruit, pulp seed ratio, number of fruits per plant, fruit yield, number of seeds per fruit, seeds weight per fruit These confirm presence of sufficient variability in the germplasm, predominance of additive gene action and high transmissibility of the characters. Therefore, direct selection will be rewarding depending upon these traits. Hence, hybridization followed by selection will be promising for improving these traits.

\section{Introduction}

The pointed gourd (Trichosanthes dioica Roxb.) which is popularly known as parwal or patal holds a coveted position in the vegetable market of our country. It is one of the most important cucurbit vegetables in tropical and subtropical regions of the world, particularly in India. It is a perennial and dioecious vegetable grown as vine with a pencil thickness stem. It is widely cultivated in Bihar, West Bengal, Odisha, Assam and Uttar Pradesh. Recently, it has been introduced in and around Hyderabad and Bangalore. The crop is cultivated over an area of 16,000 hectares in India with a production of 2 , 43,000 tonnes per hectare (NHB, 2015).

Pointed gourd is referred as king of gourds because of its higher nutrient content. The fruits are rich in vitamin $\mathrm{A}$, protein and minerals. It is easily digestible, diuretic, and laxative, invigorates the heart and brain and is useful in the disorder of the circulatory system (Malek, 2009).

The assessment of variability present in any crop species is an essential pre-requisite for 
formulating an effective breeding programme, as the existing variability can be used to enhance the yield level of cultivars following appropriate breeding strategies (Patil et al., 2012). The information on heritability alone may not help to identify characters for selection whereas heritability estimates in conjunction with predicted genetic advance is more reliable (Johnson et al., 1955). Heritability provides the information on the magnitude of inheritance of characters from parent to offspring, while genetic advance will be helpful in finding the actual gain expected under selection. Hence, the present investigation was taken up to study the variability using genetic parameters like genetic coefficient of variation, heritability and genetic advance is essential for initiating a breeding program.

\section{Materials and Methods}

The present study was conducted at the College of Horticulture, Venkataramannagudem, and West Godavari District India during Kharif season of 2016. The location falls under the Agro-climatic zone no.10, East Coast Plain and Hills (Krishna-Godavari zone) with an average rainfall of $900 \mathrm{~mm}$ at an altitude of $34 \mathrm{~m}$ (112 feet) above mean sea level. Its geographical position is $16.83^{\circ} \mathrm{N}$ latitude and $81.5^{\circ} \mathrm{E}$ longitude. It experiences hot humid summer and mild winters. The treatment comprised of twenty two genotypes of pointed gourd. Twenty two pointed gourd genotypes were collected from Odisha, West Bengal, Bihar and Jharkhand (Table 1).The experiment was laid out in a Randomize Block Design (RBD) with three replications. Recommended cultural practices were followed through the growth period to raise a good crop. Pits of size $50 \times 50 \times 30 \mathrm{~cm}$ were dug and filled with soil, cow dung and sand mixed in equal proportion Manures and fertilizers were applied as per recommendation of Rashid
(1993). $\mathrm{N}, \mathrm{P}_{2} \mathrm{O}_{5}$ and $\mathrm{K}_{2} \mathrm{O}(62.10 \mathrm{~kg}, 86.40 \mathrm{~kg}$ and $60 \mathrm{~kg}$ ) were applied in the form of Urea, Single Super Phosphate (SSP) and Muriate of Potash (MOP). All the cultural practices were followed in order with almost care and attention. The observations were recorded on main vine length, number of nodes per vine, internodal length, days to opening of first male flower appeared, days to opening of first female flower appeared, node at which first male flower appeared, node at which first female flower appeared, days to first harvest, fruit length, fruit breadth, fruit weight, pulp weight per fruit, pulp seed ratio, number of fruits per plant, fruit yield, number of seeds per fruit and seed weight per fruit.

\section{Statistical analysis}

Genotypic coefficient of variation (GCV), phenotypic coefficient of variation (PCV), Heritability, genetic advance (GA) and Genetic advance as percentage of mean were calculated as per standard formula.

Genotypic variance

Genotype MSS-Error MSS

$\left(\mathrm{V}_{\mathrm{g}}\right.$ or $\left.\sigma^{2} \mathrm{~g}\right)=$

$\mathrm{R}$

Environmental variance $\left(\mathrm{V}_{\mathrm{e}}\right.$ or $\left.\sigma^{2} \mathrm{e}\right)=$ Error mean sum of squares

Phenotypic variance $\left(\mathrm{V}_{\mathrm{p}}\right.$ or $\left.\sigma^{2} \mathrm{p}\right)=\mathrm{V}_{\mathrm{g}}+\mathrm{V}_{\mathrm{e}}$

Genotypic and phenotypic coefficients of variation

Genotypic and phenotypic coefficients of variation were estimated according to Burton and Devane (1953) by using the following formulae.

$P C V=\frac{\sqrt{\sigma_{p}{ }^{2}}}{X}$ 
$\mathrm{GCV}=\frac{\sqrt{\sigma_{\mathrm{g}}^{2}}}{\frac{\mathrm{X}}{\mathrm{X}}} \mathrm{x} 100$

Where,

GCV = Genotypic coefficient of variation

$\mathrm{PCV}=$ Phenotypic coefficient of variation

$\sigma_{\mathrm{g}}^{2}=$ Genotypic variance

$\sigma_{\mathrm{p}}^{2}=$ Phenotypic variance

$\bar{X}=$ General mean of the character

PCV and GCV were classified (Sivasubramanian and Menon, 1973) as shown below.

$0-10 \%=$ Low

$10-20 \%=$ Moderate

$21 \%$ and above $=$ High

Heritability in Broad sense [h2 (b)]

Heritability in broad sense was estimated as per the formulae suggested by Allard (1960).

$h^{2}(b)=\frac{\sigma_{g}^{2}}{\sigma_{p}{ }^{2}} \times 100$

Where,

$h^{2}(b)=$ Heritability estimates in broad sense

$\sigma_{\mathrm{g}}^{2}=$ Genotypic variance

$\sigma_{\mathrm{p}}^{2}=$ Phenotypic variance

As suggested by Johnson et al., (1955), $\mathrm{h}^{2}$ (b) estimates were categorised as $\begin{array}{ll}\text { Low } & =0-30 \% \\ \text { Medium } & =31-60 \% \\ \text { High } & =61 \% \text { and above }\end{array}$

\section{Genetic advance (GA)}

This was estimated as per formula proposed by Allard (1960)

$\mathrm{GA}=\mathrm{Kx} \sigma_{\mathrm{p}} \times \mathrm{h}^{2}(\mathrm{~b})$

Where,

$\mathrm{K}=$ Selection differential at 5 per cent selection intensity which accounts to a constant value 2.06

$\mathrm{h}^{2}(\mathrm{~b})=$ Heritability in broad sense

$\sigma_{\mathrm{p}}=$ Phenotypic standard deviation

\section{Genetic advance as per cent of mean (GAM)}

Genetic advance over mean (GAM) was calculated using the following formula and was expressed in percentage.

GAM $=\frac{\text { GA }}{-----}$ x 100

Where,

$\mathrm{GA}=$ genetic advance

$\overline{\mathrm{X}}=$ general mean of the character

The genetic advance as per cent over mean was categorized as suggested by Johnson et al., (1955) and is mentioned below:

$0-10 \%=$ Low 
$10-20 \%=$ Moderate

$21 \%$ and above $=$ High

\section{Results and Discussion}

The investigation for present of variability in twenty two genotypes of pointed gourd was measured in term of range, phenotypic coefficient of variation (PCV), genotypic coefficient of variance (GCV), heritability (broad sense) and genetic advance.

The analysis of variance for seventeen characters (Table 2) revealed highly significant differences for all the characters indicating the existence of enormous amount of genetic variability for growth and yield attributes.

The mean values, coefficient of variation, heritability and genetic advance value for sixteen characters are presented in table 3.

Wide range of variation observed for all the characters. Components of variation estimated for all the traits indicated wide range of variability in main vine length $(4.32-6.07 \mathrm{~m})$, number of nodes per vine (35.30-64.33), internodal length $(7.10-17.21 \mathrm{~cm})$, days to opening of first male flower appeared (70.6688.00), days to opening of first female flower appeared (75.06-93.36), node at which first male flower appeared (7.00-13.00), node at which first female flower appeared (10.0018.00), days to first harvest (90.00-120.00), fruit length $(5.10-11.20 \mathrm{~cm})$, fruit breadth $(3.08-5.26 \mathrm{~cm})$, fruit weight $(20-42 \mathrm{~g})$, Pulp weight per fruit (14.00-38g), Pulp seed ratio (4.45-17.91) number of fruits per plant (30.00-62.30), Fruit yield (5.59-24.26 t/ha), number of seeds per fruit (12.12-36.56) and seed weight per fruit (1.93-4.41g) which indicated that there is better scope for selection for the improvement of these characters. These findings are in proximity with the results of Singh et al., (1985), Yawalkar (1985), Shanmugavelu (1989), Singh and Prasad (1989), Prasad and Singh (1990), Dora et al.,(2002), khan et al.,(2009) and Bharathi and vishalnath (2010a) in pointed gourd.

The studies suggest that it can possible to isolate superior genotypes during the selection process.

In the present study, wide variability was recorded for fruit yield ( $t /$ ha),fruit weight $(g)$,pulp weight per fruit, pulp seed ratio, number of seeds per fruit, intermodal length indicating the existence of more variability for these traits among the genotypes under study as they have high PCV and high GCV.

Moderate to low variability was recorded for main vine length, number of nodes per vine, days to opening of first male flower, days to opening of first female flower, node at which first male flower appeared, node at which first female flower appeared, days to first harvest, fruit length, number of fruits per plant and seed weight per fruit.

Phenotypic coefficient of variation (PCV) was higher than genotypic coefficient of variation (GCV) for all the traits under study indicating that environmental factors were influencing the expression of these traits.

Wide difference between phenotypic and genotypic coefficient of variation indicating their sensitiveness to environmental fluctuations whereas narrow difference showed less environmental interference on the expression of these traits. The traits which showed high phenotypic and genotypic coefficient of variation are of economic importance and there is an immense scope for improvement of these traits through selection programme. 
Table.1 Genotypes and Source of 22 pointed gourd germplasm

\begin{tabular}{|l|l|l|}
\hline Genotype number & Name of the genotype & Source \\
\hline $\mathrm{G}_{1}$ & Chandramukhi & Odisha \\
\hline $\mathrm{G}_{2}$ & Bengal Jyoti & West Bengal \\
\hline $\mathrm{G}_{3}$ & Khandagiri & Odisha \\
\hline $\mathrm{G}_{4}$ & Bengal Rani & West Bengal \\
\hline $\mathrm{G}_{5}$ & Ghanti Keshari & Odisha \\
\hline $\mathrm{G}_{6}$ & Rayagada local & Odisha \\
\hline $\mathrm{G}_{7}$ & Coochbehar local & West Bengal \\
\hline $\mathrm{G}_{8}$ & Nandini & Odisha \\
\hline $\mathrm{G}_{9}$ & Gaya local & Bihar \\
\hline $\mathrm{G}_{10}$ & Ghia potol & Odisha \\
\hline $\mathrm{G}_{11}$ & Madanpur local-1 & West Bengal \\
\hline $\mathrm{G}_{12}$ & Puri local-1 & Odisha \\
\hline $\mathrm{G}_{13}$ & Pipli local & Odisha \\
\hline $\mathrm{G}_{14}$ & Puri local-2 & Odisha \\
\hline $\mathrm{G}_{15}$ & Patna local & Bihar \\
\hline $\mathrm{G}_{16}$ & Swarna Alaukik & Jharkhand \\
\hline $\mathrm{G}_{17}$ & Buguda local & Odisha \\
\hline $\mathrm{G}_{18}$ & Madanpur local-2 & West Bengal \\
\hline $\mathrm{G}_{19}$ & Jharkhand local-1 & Jharkhand \\
\hline $\mathrm{G}_{20}$ & Jharkhand local-2 & Jharkhand \\
\hline $\mathrm{G}_{21}$ & Sakhigopal local & Odisha \\
\hline $\mathrm{G}_{22}$ & Bhubaneswar local & Odisha \\
\hline & & \\
\hline
\end{tabular}

Table.2 Analysis of variance for various characters in pointed gourd genotypes

\begin{tabular}{|c|c|c|c|c|}
\hline \multirow{2}{*}{ S.No } & \multirow{2}{*}{ Characters } & \multicolumn{3}{|c|}{ Mean sum of squares } \\
\hline & & Replications $(\mathrm{df}=\mathbf{2})$ & Treatments $(\mathrm{df}=\mathbf{2 1})$ & Error $(\mathrm{df}=42)$ \\
\hline 1. & Main vine length & 0.50 & $1.41^{* *}$ & 0.29 \\
\hline 2. & Number of nodes per vine & 2.17 & $243.13^{* *}$ & 6.41 \\
\hline 3. & Internodal length $(\mathrm{cm})$ & 1.57 & $38.66^{* *}$ & 1.01 \\
\hline 4. & Days to opening of first male flower & 37.51 & $45.06^{* *}$ & 16.66 \\
\hline 5. & Days to opening of first female flower $f$ & 0.32 & $43.21^{* *}$ & 18.68 \\
\hline 6. & Node at which first male flower appeared & 1.77 & $8.04^{* *}$ & 1.13 \\
\hline 7. & $\begin{array}{l}\text { Node at which first female flower } \\
\text { appeared }\end{array}$ & 1.98 & $10.25^{* *}$ & 1.17 \\
\hline 8. & Days to first harvest (d) & 5.79 & $169.42^{* *}$ & 62.03 \\
\hline 9. & Fruit length $(\mathrm{cm})$ & 1.28 & $7.78^{* *}$ & 1.01 \\
\hline 10. & Fruit breadth $(\mathrm{cm})$ & 0.13 & $0.85^{* *}$ & 0.14 \\
\hline 11. & Fruit weight (g) & 7.07 & $147.78^{* * *}$ & 6.62 \\
\hline 12. & Pulp weight per fruit (g) & 10.02 & $163.05^{* *}$ & 6.17 \\
\hline 13. & Pulp seed ratio & 0.01 & $38.46^{* *}$ & 0.96 \\
\hline 14. & Number of fruits per plant & 12.76 & $184.69^{* *}$ & 6.06 \\
\hline 15. & Fruit Yield (t/ ha) & 6.02 & $70.24^{* * *}$ & 2.57 \\
\hline 16. & Number of seeds per fruit & 1.34 & $107.38^{* *}$ & 8.76 \\
\hline 17. & Seed weight per fruit (g) & 0.14 & $1.14^{* * *}$ & 0.08 \\
\hline
\end{tabular}

$*, * *=$ significant at $5 \%$ and $1 \%$ level respectively. 
Table.3 Estimates of variability, heritability and genetic advance as per cent of mean for different characters in pointed gourd genotypes

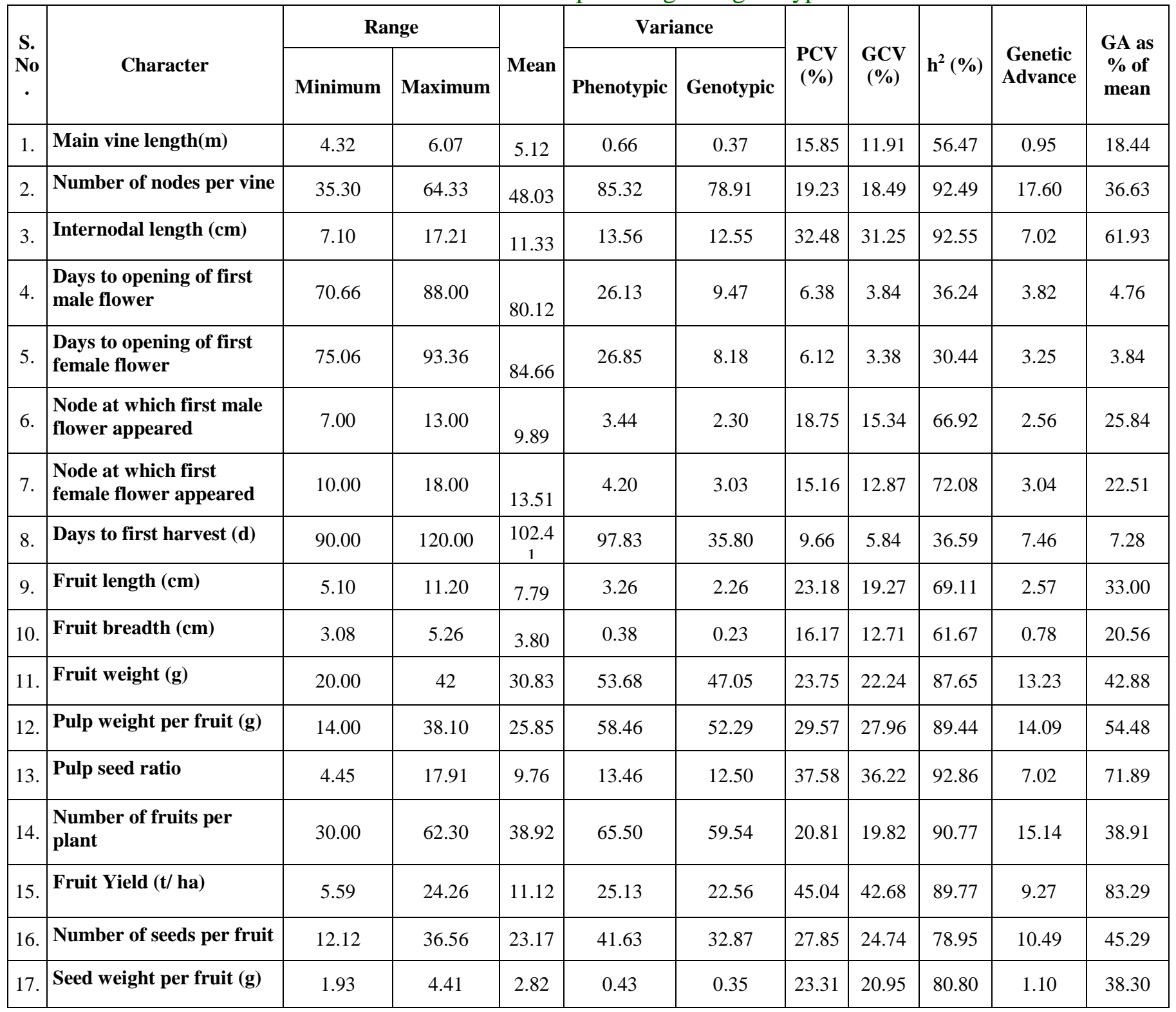

The estimation of genetic coefficient of variation indicates the amount of genetic variation present for different traits while the heritability gives an insight into the proportion of variation which is inherent. Heritability estimate provide the information regarding the amount of transmissible genetic variation to total variation and determine genetic improvement and response to selection. Heritability estimate along genetic advance are normally more useful in predicting the gain under selection than that of heritability alone. However, it is not necessary that characters showing high heritability will also exhibit high genetic advance (Johnson et al., 1955).

High heritability coupled with high genetic advance as per cent of mean indicates the operation of additive gene action as in case of number of nodes per vine, internodal length, node at which first female flower appeared, 
fruit length, fruit weight, pulp weight per fruit, pulp seed ratio, number of fruits per plant, fruit yield, number of seeds per fruit and seeds weight per fruit. Hence, direct selection based on these traits in genetically diverse material could be effective for desired improvement. Moderate genetic advance as per cent of mean with high or moderate heritability indicates the action of both additive and non-additive genes as in case of days to opening of first male flower, days to opening of first female flower, node at which first male flower appeared and days to first harvest.

\section{Acknowledgement}

The author is highly thankful to the Dr. Y.S.R.H.U, College of Horticulture, Andhra Pradesh for providing the experimental material as well as lab and other facilities during the research work.

\section{References}

Allard, R.W. 1960. Principles of plant breeding. John Wiley \& Sons, New York, USA. pp 485.

Bharathi, L.K. and Vishalnath. 2010a. phenotypic diversity analysis in pointed gourd. (Trichosanthes dioica Roxb.).Cucurbit Genetics Cooperative Report. Central Horticultural Experiment Station (IIHR). 33-34:62-64.

Burton, G. W. 1952. Quantitative inheritance in grasses. Proc. 6th Int. Grass land Cong. 1:227283.

Burton, G.W. and Devane, E.H. 1953. Estimating the heritability in tall fescue (Festuca arundinancea) from replicated clonal material. Agronomy Journal. 45: 478-481.

Dora, D. K., Behera, T., Acharya, G.C., Mahapatra, P. and Mishra, B. 2002. Genetic variability and character association in pointed gourd (Trichosanthes dioica Roxb.). Indian Journal of Horticulture. 60(2): 163-168.

Johnson, H. W., Robinson, H. F. and Comstock, R. E. 1955. Estimates of genetic and environmental variability in soybean. Agronomy Journal. 47:314-318.

Khan, A.S.M.M.R., Kabier, M. Y. and Alam, M.M. 2009. Variability, correlation path analysis of yield and yield components of pointed gourd. Journal of Agricultural Rural Development. 7(1\&2): 93-98.

Malek, M. A. 2009. In vitro propagation of pointed gourd (Trichosanthes dioica Roxb.) Through encapsulated shoot tips. Bangladesh Journal of Agrilculture Research. 34 (4): 555-563.

National Horticulture Board. 2015. Third advanced estimation of area and production of horticulture crops; Ministry of Agriculture, Govt. of India. nhb.gov.in.

Patil, P.R., Surve, V.H., Mehta H.D. (2012): Line x Tester analysis in Rice (Oryza sativa L.). Madras Agriculture Journal.99:210-213.

Prasad, V. S. R. K. and Singh, D. P. 1990. Genotype $\mathrm{x}$ environment interaction in pointed gourd (Tricosanthes dioica). Indian Journal of Horticulture. 47(1): 75-78.

Rashid, M. M. 1993. Vegetable Science (in Bangla). Bangla Academy, Dhaka. Bangladesh, pp. 333336.

Shanmugavelu, K. G. 1989. Production technology of vegetable Crops. Oxford and IBH Publishing Co. New Delhi, India, pp. 821-825.

Singh, D. P. and Prasad, V. S. R. K. 1989. Variability and correlation studies in pointed gourd (Trichosanthes dioica). Indian Journal of Horticulture. 46(2):204-209.

Singh, R. R., Mishra, G. M. and Jha, R. N. 1985. Studies on varieties and scopes for improvement in pointed gourd (Tricosanthes dioica). South Indian Horticulture. 33(4): 257-260

Yawalkar, K. S. 1985. Vegetable crops of India. Agri-Horticultural Publishing House, Nagpur, India. pp. 178-182.

\section{How to cite this article:}

Anil Kumar Jena, T. Suseela, T.S.K.K. Kiran Patro and Sujatha, R.V. 2017. Studies on Genetic Variability, Heritability and Genetic Advance in Pointed Gourd (Trichosanthes dioica Roxb.). Int.J.Curr.Microbiol.App.Sci. 6(8): 1857-1863. doi: https://doi.org/10.20546/ijcmas.2017.608.219 